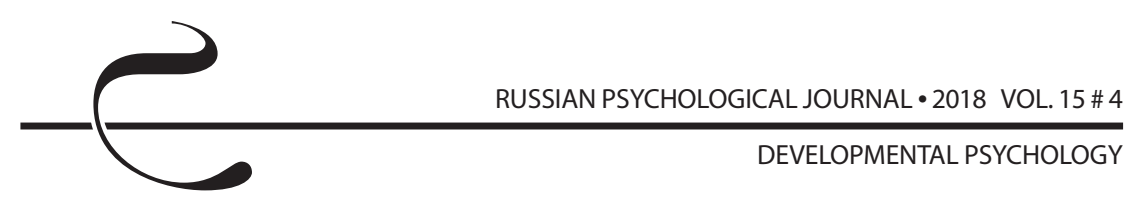

УДК 159.923.2

DOI: $\underline{10.21702 / r p j .2018 .4 .6}$

\title{
Устойчивость и изменчивость идентичности в подростковом и юношеском возрасте
}

\author{
Михаил Ю. Кузьмин ${ }^{1,2^{*}}$, Игорь А. Конопак ${ }^{2}$ \\ 1 Федеральное государственное бюджетное научное учреждение «Научный центр \\ проблем здоровья семьи и репродукции человека», г. Иркутск, \\ Российская Федерация \\ ${ }^{2}$ Иркутский государственный университет, г. Иркутск, Российская Федерация \\ *E-mail: $\underline{\text { mirroy@mail.ru }}$
}

\begin{abstract}
Аннотация
Введение. В статье рассматривается проблема кризиса идентичности с точки зрения устойчивости и изменчивости ее основных компонентов. Новизна исслеАОвания заключается в анализе стабильности отАельных компонентов иАентичности на протяжении поАросткового и юношеского возраста, выраженных в устойчивости отАельных самоописаний, при репрезентации своего прош^ого и будущего, а также при разработке конструктов.
\end{abstract}

Методы. Авторы используют методики: «Авадцать утвержАений» М. Куна и Т. МакПартленАа, «Твоя Аиния жизни» А. Кроника, тест личностных конструктов Аж. Кел^и. Результаты. У поАростков снижается АОАя Аичностного И эКзистенциального Компонентов илентичности, а Аоля учебного компонента возрастает. У испытуемых юношеского возраста при росте семейной иАентичности снижаются иАентичность, связанная с членством в нефрормальных группах, и деятельностный компонент. В субъективной репрезентации своей жизни у поАростков и юношей основными являются такие компоненты, как полоролевой, учебно-профрессиональный, семейный и ^ичностный. Основная Аинамика субъективной репрезентации прош^ого присуща полросткам. У подростков наиболее устойчивы самоописания, относящиеся к Аичностной иАентичности, а у юношей - к ее социальному компоненту. Показано, что устойчивыми компонентами субъективной картины прошлого и будущего в поАростковом и юношеском возрасте являются события, относящиеся к учебной, семейной сорерам, а также к членству в нефрормальных группах. Наконец, выяснено, что у испытуемых юношеского возраста устойчивы конструкты, относящиеся к качествам мичности, своему семейному статусу, межличностным отношениям и учебно-продрессиональной Аеятельности.

ОбсужАение результатов. Авторы сравнивают полученные им результаты с работами как отечественных (Г. Б. Мазилова, А. В. Микляева, Т. В. Румянцева и Ар.), так и зарубежных (E. Crocetti, W. Meeus, Z. Abdukeram) авторов. Анализируются раз^ичия в полученных результатах, обусловленные разницей в выборках, культурных 
аспектах, а также подходах к изучаемой проблеме (использование трехкомпонентной модели зарубежными авторами).

\section{КАючевые слова}

ИАентичность, УстоЙчивость ИАентичности, Изменчивость иАентичности, кризис иАентичности, социальная иАентичность, Аинамика иАентичности, генАерная иАентичность, пОАРОСткИ, Юношество

\section{Основные положения}

- у испытуемых полросткового возраста, наряду с тенденцией к снижению Аоли характеристик ^ичности, используемых А^я самоописания, происхоАит рост АОАи самоописаний, связанных с учебной Аеятельностью;

- в полростковом возрасте, чем большую Аолю занимает тот или иной компонент илентичности, тем более Аифрореренцированным он оказывается и тем менее ск^онен испытуемый к повторному использованию самоиАентификаций; при этом наиболее устойчивы самоописания, относящиеся к личностной иАентичности; - у испытуемых юношеского возраста семейная идентичность устойчиво растет на всем протяжении студенчества, а деятельностный компонент и членство в недрормальных группах снижаются; наиболее устойчивые илентифрикации на всем протяжении юношеского возраста относятся к социальному компоненту иАентичности; - у испытуемых юношеского возраста основные конструкты связаны с генАерной иАентичностью, качествами Аичности и межличностными связями; при этом самыми устойчивыми оказываются конструкты, относящиеся к качествам мичности, своему семейному статусу, межличностными отношениями и учебно-профрессиональной Аеятельности;

- при репрезентации своего прошлого и будущего наиболее устойчивыми компонентами являются события, связанные с учебно-профрессиональными, семейными аспектами или с приналмежностью к различным малым группам.

\section{Для цитирования}

Кузьмин М. Ю., Конопак И. А. Устойчивость и изменчивость идентичности в подростковом и юношеском возрасте // Российский психологический журнал. 2018. Т. 15, № 4. C. 113-141. DOI: 10.21702/rpj.2018.4.6

Материалы статьи получены 15.03.2018 
UDC 159.923 .2

DOI: $\underline{10.21702 / r p j .2018 .4 .6}$

\title{
Stability and Variability of Identity in Schoolchildren and Students
}

\author{
Mikhail Y. Kuzmin ${ }^{1,2 *}$, Igor' A. Konopak ${ }^{2}$ \\ 1 Scientific Center for Family Health and Human Reproduction Problems, Irkutsk, Russian \\ Federation \\ ${ }^{2}$ Irkutsk State University, Irkutsk, Russian Federation \\ *Corresponding author. E-mail: mirroy@mail.ru
}

\begin{abstract}
Introduction. This paper considers identity crisis from the viewpoint of stability and variability of its main components. To that end, an exploratory study has examined a relatively unexplored issue of stability of certain components of identity in schoolchildren and university students when they represent their past and future in self-descriptions.
\end{abstract}

Methods. The study used the following techniques: (a) the Twenty Statements Test by Kuhn and McPartland, (b) Your Lifeline by Kronik, and (c) the Test of Kelly Personal Constructs (a modified version).

Results. The study discovered that schoolchildren use educational component of identity in their self-descriptions more often than personal and existential ones. In student respondents, the increase in the level of family identity is typically accompanied by the reduced level of identity related to membership in informal groups and activity component. Gender, educational-professional, family, and personal identity components are prevalent in both schoolchildren and students' subjective representations of their lives. However, schoolchildren demonstrate a greater dynamics of subjective representations of the past. Self-descriptions related to personal identity are the most stable in students, whereas in schoolchildren the most stable are self-descriptions related to the social component. Events related to education, family, and membership in informal groups are stable components of the subjective image of the past and future in schoolchildren and students. Finally, the findings suggest that students have stable constructs related to personality traits, family status, interpersonal relationships, and educational and professional activities.

Discussion. The authors compare their findings with the works of Mazilova, Miklyaeva, Rumyantseva, Crocetti, Meeus, and Abdukeram. The paper analyzes and discusses the difference in findings of studies that exercised different conceptual approaches to the identity issue (e.g., a heavy reliance on a three-component model in the western researcher tradition) and were based on different samples with diverse cultural backgrounds. 


\section{Keywords}

identity, identity stability, identity variability, identity crisis, social identity, identity dynamics, gender identity, schoolchildren, students

\section{Highlights}

- Schoolchildren's self-descriptions provide fewer personality characteristics, whereas the number of self-descriptions related to educational activities increases.

- In students, a higher proportion of any individual component of identity determines its higher differentiation. In such a case individuals are less inclined to engage in re-self-identification. Meanwhile, self-descriptions related to personal identity are the most stable. - Family identity steadily increases throughout student life, while the activity component and membership in informal groups decrease. Students' most stable identities are related to their social component.

- Student respondents' main constructs are related to gender identity, personality traits, and interpersonal relationships. The most stable constructs are those related to personality traits, family status, interpersonal relationships and educational and professional activities. - Events related to educational-professional and family aspects and membership in various small groups are the most stable components in self-representations of the past and future.

\section{For citation}

Kuzmin M. Y., Konopak I. A. Stability and Variability of Identity in Schoolchildren and Students. Rossiiskii psikhologicheskii zhurnal-Russian Psychological Journal, 2018, V. 15, no. 4, pp. 113-141 (in Russian). DOI: 10.21702/rpj.2018.4.6

\section{Введение}

Original manuscript received 15.03.2018

Проблема кризиса идентичности в современной отечественной психологии продолжает привлекать внимание ведущих отечественных исследователей. Одной из причин этого является неодинаковая трактовка самого понятия кризиса идентичности. Как указала Е. П. Белинская, вопрос проблематики идентичности - вопрос ее изменчивости/устойчивости - исторически разрешается, скорее, в пользу ее изменчивости [1]. Если первоначально (начиная с У. Джеймса, затем у Ч. Кули и Дж. Г. Мида, завершая Э. Фроммом и Э. Эриксоном), идея Я и идентичности рассматривалась как априорно интегрирующая «инстанции» личности, то постепенно такая точка зрения уступила место представлениям о ее изменчивости и вариативности (например, в теории Г. Брейкуэлл [2], работах Х. Маркус [3], Н. Л. Ивановой [4] и т. д).

Вместе с тем, на наш взгляд, изучение идентичности только как подвижной системы ведет к выхолащиванию как отдельных понятий, связанных с ней, так 




и самой ее сути. Становится затруднительным определение понятия «кризис идентичности», поскольку не ясно, какие именно изменения в ее структуре признавать кризисными.

Одним из способов решения данной проблемы, по нашему мнению, является выделение устойчивых компонентов идентичности для того или иного возрастного этапа. Попытки выделить такие компоненты предпринимались как в отечественных, так и в зарубежных работах. Можно указать исследования T. A. Klimstra et al. (изучалась устойчивость идентичности в подростковом возрасте) [5], работу W. Meeus, (метаанализ лонгитюдных исследований стабильности отдельных статусов идентичности у подростков) [6], E. Crocetti et al. (изучение коррелятов стабильности статусов идентичности у подростков и испытуемых юношеского возраста) [7]. Г. Б. Мазилова выделила компоненты, более подверженные социальным изменениям в подростковом возрасте (этнические, гражданские, рефлексивные, физические характеристики идентичности) и практически стабильные (статусно-ролевые, полоролевые и глобальные показатели) [8].

На наш взгляд, изучение особенностей структур идентичности, которые, с одной стороны, являются ведущими для того или иного возрастного этапа, а, с другой стороны, отличаются устойчивостью, позволит определить «ядро» идентичности, выделить идентификации, определяющие успешное прохождение нормативных кризисов и оберегающие идентичность от разрушения в ситуации радикальных социальных катаклизмов. Отсюда целью нашего исследования стало рассмотрение устойчивых компонентов идентичности у испытуемых подросткового и юношеского возраста. Для этого на первом этапе мы уточнили особенности динамики компонентов идентичности у испытуемых подросткового и юношеского возраста. На втором этапе мы выявляли конкретные самоописания, относящиеся к отдельным компонентам идентичности, и их устойчивость на протяжении подросткового и юношеского возраста.

\section{Методы}

Изучение устойчивости тех или иных компонентов идентичности сопряжено с рядом проблем. Отчасти устойчивость компонентов идентичности можно отследить, учитывая ранги, присваиваемые испытуемым тому или иному самоописанию (используется, например, в модификации методики Т. В. Румянцевой [9]). Этот подход, по-видимому, использовался Г. Б. Мазиловой, отмечавшей стабильность соответствующего компонента в целом - без анализа конкретных характеристик, приписываемых испытуемым самому себе [8]. Однако в этом случае может быть утрачено конкретное содержание, которым испытуемый наполняет соответствующий компонент идентичности. 
На наш взгляд, для изучения устойчивости тех или иных компонентов идентичности следует использовать не только ранги, присваиваемые понятиям, отражающим соответствующую идентичность. Плодотворным может быть также анализ того, насколько стабильны сами самокатегоризации, которые использует испытуемый: повторяются ли они по мере взросления испытуемых, в каких обстоятельствах меняются.

Таким образом, для изучения стабильности идентичности мы использовали методику «Двадцать утверждений» М. Куна и Т. МакПартленда [10], обработка которой осуществлялась рядом способов:

- при помощи авторского классификатора рассчитывались компоненты идентичности в зависимости от частоты упоминаний относящихся к ним характеристик. Это позволяет, с одной стороны, определить, является ли сам по себе компонент устойчивым, доминирующим, а, с другой стороны, определить направление его развития;

- сравнивались сами характеристики, используемые испытуемым для самоописания. Это позволяет, исходя из числа совпадений, рассчитать устойчивость идентичности, к которой относились данные характеристики.

Совмещение данных способов, на наш взгляд, позволяло проанализировать различные аспекты идентичности. Если подсчет отдельных самоидентификаций отражает содержательный аспект идентичности, то изучение повторного использования отдельных идентификаций - устойчивость представлений о самом себе.

Кроме того, мы использовали методику «Твоя линия жизни» А. Кроника в его бланковом варианте [11] для определения устойчивости и изменчивости временного компонента идентичности испытуемых, а также - на выборке студентов - тест личностных конструктов Дж. Келли [12] для анализа устойчивости сложившейся системы конструктов личности.

Полученные данные обрабатывались при помощи корреляционного анализа, t-критерия Стьюдента, нормализованного z-критерия, углового коэффициента Фишера с привлечением пакета SPSS21.

\section{Результаты}

Исследование проводилось на выборке из 500 испытуемых, включающих испытуемых подросткового и юношеского возраста (таблица 1) в период с 2012-го по 2017-й год на базе ФГБОУ ВО «ИГУ» (Выборка юношей), МАОУ ЦО № 47 (г. Иркутск) и МОУ ИРМО «Максимовская СОШ» (с. Максимовщина, Иркутская область) (выборка подростков). Первоначальный состав выборки включал 250 испытуемых подросткового и 250 испытуемых юношеского возраста. Анализ состава испытуемых в выборке на разных этапах представлен в таблице 1 . 
Таблица 1. Состав выборки испытуемых на начальном и заключительном этапах

Table 1. Sample composition at the initial and final stages of the study

\begin{tabular}{|c|c|c|c|c|c|}
\hline $\begin{array}{l}\text { Этan } \\
\text { Stages }\end{array}$ & $\begin{array}{c}\text { Пом } \\
\text { Gender }\end{array}$ & $\begin{array}{c}\text { Bозраст } \\
\text { Age }\end{array}$ & $\begin{array}{c}\text { Подростки } \\
\text { Schoolchildren }\end{array}$ & $\begin{array}{l}\text { Юноши } \\
\text { Students }\end{array}$ & $\begin{array}{l}\text { Итого } \\
\text { Overall }\end{array}$ \\
\hline \multirow{4}{*}{$\begin{array}{l}\text { Начальный } \\
\text { этап } \\
\text { Initial } \\
\text { stage }\end{array}$} & \multirow{2}{*}{$\begin{array}{l}\text { Мужской } \\
\text { Male }\end{array}$} & Чис^о п & 119 & 112 & 231 \\
\hline & & $\%$ & $23,8 \%$ & $22,4 \%$ & $46,2 \%$ \\
\hline & \multirow{2}{*}{$\begin{array}{l}\text { Женский } \\
\text { Female }\end{array}$} & Число n & 131 & 138 & 269 \\
\hline & & $\%$ & $26,2 \%$ & $27,6 \%$ & $53,8 \%$ \\
\hline \multirow{4}{*}{$\begin{array}{l}\text { Заклю- } \\
\text { чительный } \\
\text { этап } \\
\text { Final stage }\end{array}$} & \multirow{2}{*}{$\begin{array}{l}\text { Мужской } \\
\text { Male }\end{array}$} & Число n & 113 & 99 & 212 \\
\hline & & $\%$ & $24,8 \%$ & $21,8 \%$ & $46,6 \%$ \\
\hline & \multirow{2}{*}{$\begin{array}{l}\text { Женский } \\
\text { Female }\end{array}$} & Чис^о n & 122 & 121 & 243 \\
\hline & & $\%$ & $26,8 \%$ & $26,6 \%$ & $53,4 \%$ \\
\hline
\end{tabular}

\section{Анализ динамики идентичности в подростковом возрасте}

Прежде всего мы проанализировали динамику отдельных компонентов идентичности подростков в период с 2012-го по 2017-й год (соответствует обучению учащихся в 5-9 классах образовательной школы).

Таблица 2. Аинамика отАельных компонентов иАентичности поАростков

Table 2. Dynamics of components of identity in schoolchildren

\begin{tabular}{|c|c|c|c|c|c|c|c|c|c|c|}
\hline \multirow{2}{*}{$\begin{array}{c}\text { Компо- } \\
\text { ненты } \\
\text { Compo- } \\
\text { nents }\end{array}$} & \multicolumn{2}{|c|}{$\begin{array}{c}5-\check{n} \\
\text { 5th form }\end{array}$} & \multicolumn{2}{|c|}{$\begin{array}{c}\text { 6-й } \\
\text { 6th form }\end{array}$} & \multicolumn{2}{|c|}{$\begin{array}{c}\text { 7-й } \\
\text { 7th form }\end{array}$} & \multicolumn{2}{|c|}{$\begin{array}{c}\text { 8-й } \\
\text { 8th form }\end{array}$} & \multicolumn{2}{|c|}{$\begin{array}{c}9-\bar{~} \\
\text { 9th form }\end{array}$} \\
\hline & $\begin{array}{l}\text { Чис- } \\
10 \\
n\end{array}$ & $\%$ & $\begin{array}{c}4 \text { чис- } \\
10 \\
n\end{array}$ & $\%$ & $\begin{array}{c}4 и с- \\
10 \\
n\end{array}$ & $\%$ & $\begin{array}{c}4 и с- \\
10 \\
n\end{array}$ & $\%$ & $\begin{array}{l}\text { Чис- } \\
10 \\
n\end{array}$ & $\%$ \\
\hline $\begin{array}{l}\text { Полоро- } \\
\text { ^евой } \\
\text { Gender }\end{array}$ & 70 & $4,6 \%$ & 119 & $6,3 \%$ & 69 & $4,0 \%$ & 96 & $5,1 \%$ & 112 & $5,7 \%$ \\
\hline $\begin{array}{l}\text { Учебный } \\
\text { Educa- } \\
\text { tional }\end{array}$ & 80 & $5,3 \%$ & 107 & $5,7 \%$ & 116 & $6,7 \%$ & 143 & $7,6 \%$ & 166 & $8,5 \%$ \\
\hline
\end{tabular}




\begin{tabular}{|c|c|c|c|c|c|c|c|c|c|c|}
\hline \multirow{2}{*}{$\begin{array}{c}\text { Компо- } \\
\text { ненты } \\
\text { Compo- } \\
\text { nents }\end{array}$} & \multicolumn{2}{|c|}{$\begin{array}{c}5-\check{~} \\
5 \text { th form }\end{array}$} & \multicolumn{2}{|c|}{$\begin{array}{c}\text { 6-й } \\
\text { 6th form }\end{array}$} & \multicolumn{2}{|c|}{$\begin{array}{c}\text { 7-й } \\
\text { 7th form }\end{array}$} & \multicolumn{2}{|c|}{$\begin{array}{c}\text { 8-й } \\
\text { 8th form }\end{array}$} & \multicolumn{2}{|c|}{$\begin{array}{c}\text { 9-й } \\
\text { 9th form }\end{array}$} \\
\hline & $\begin{array}{l}\text { Чис- } \\
10 \\
n\end{array}$ & $\%$ & $\begin{array}{l}\text { Чис- } \\
10 \\
n\end{array}$ & $\%$ & $\begin{array}{c}\text { Чис- } \\
10 \\
n\end{array}$ & $\%$ & $\begin{array}{c}\text { Чис- } \\
\wedge 0 \\
n\end{array}$ & $\%$ & $\begin{array}{c}\text { Чис- } \\
10 \\
n\end{array}$ & $\%$ \\
\hline $\begin{array}{l}\text { Семейный } \\
\text { Family }\end{array}$ & 132 & $8,7 \%$ & 232 & $12,3 \%$ & 243 & $14,1 \%$ & 227 & $12,1 \%$ & 257 & $13,1 \%$ \\
\hline $\begin{array}{l}\text { Этни- } \\
\text { ческий } \\
\text { Ethnic }\end{array}$ & 27 & $1,8 \%$ & 49 & $2,6 \%$ & 45 & $2,6 \%$ & 79 & $4,2 \%$ & 75 & $3,8 \%$ \\
\hline $\begin{array}{l}\text { Аичност- } \\
\text { ный } \\
\text { Personal }\end{array}$ & 753 & $49,4 \%$ & 842 & $44,7 \%$ & 820 & $47,5 \%$ & 817 & $43,5 \%$ & 805 & $41,0 \%$ \\
\hline $\begin{array}{l}\text { Коммуни- } \\
\text { кативный } \\
\text { Commu- } \\
\text { nicative }\end{array}$ & 42 & $2,8 \%$ & 84 & $4,5 \%$ & 82 & $4,8 \%$ & 77 & $4,1 \%$ & 80 & $4,1 \%$ \\
\hline $\begin{array}{l}\text { Аеятель- } \\
\text { ностный } \\
\text { Activity }\end{array}$ & 66 & $4,3 \%$ & 144 & $7,7 \%$ & 79 & $4,6 \%$ & 86 & $4,6 \%$ & 106 & $5,4 \%$ \\
\hline $\begin{array}{l}\text { Перспек- } \\
\text { тивный } \\
\text { Prospective }\end{array}$ & 9 & $0,6 \%$ & 4 & $0,2 \%$ & 11 & $0,6 \%$ & 3 & $0,2 \%$ & 6 & $0,3 \%$ \\
\hline $\begin{array}{l}\text { Групповой } \\
\text { Group }\end{array}$ & 130 & $8,5 \%$ & 83 & $4,4 \%$ & 96 & $5,6 \%$ & 183 & $9,7 \%$ & 201 & $10,2 \%$ \\
\hline $\begin{array}{l}\text { Экзистен- } \\
\text { циальный } \\
\text { Existential }\end{array}$ & 214 & $14,1 \%$ & 218 & $11,6 \%$ & 164 & $9,5 \%$ & 169 & $9,0 \%$ & 156 & $7,9 \%$ \\
\hline
\end{tabular}

Согласно полученным данным, можно выделить следующие особенности динамики компонентов идентичности:

- в самом начале подросткового возраста увеличивается выраженность как в абсолютных, так и в относительных значениях практически всех компонентов идентичности: полоролевого (рост с 4,6 \% до 6,3 \%, Z = 4,32, $\mathrm{p}<0,01$ ), семейного (рост с 8,7\% до 12,3\%, Z = 2,7, p < 0,01), этнического (рост с 1,8\% до 2,6\%, $Z=2,84, p<0,01$ ), коммуникативного (рост 


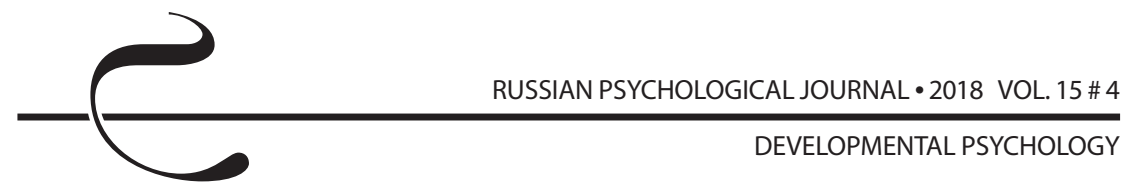

с 2,8\% до 4,5\%, Z = 3,1, p < 0,01), деятельностного (рост с 4,3\% до 7,7\%, $\mathrm{Z}=3,97, \mathrm{p}<0,01)$. Наоборот, выраженность идентичности с различными неформальными группами снижается (с 8,5\% до 4,4 \%, Z = 2,15, p < 0,03);

- к середине подросткового возраста рост основных компонентов идентичности замедляется. Хотя в процентном соотношении происходит рост выраженности семейного (с $12,3 \%$ до 14,1\%), учебного (с 5,7\% до 6,7\%) компонентов, однако значимых различий обнаружить не удалось. Наоборот, значимо снижается выраженность полоролевого (снижение с $6,3 \%$ до $4 \%, Z=-4,1, p<0,01$ ), деятельностного (снижение с $7,7 \%$ до $4,6 \%, Z=-2,4, p<0,01$ ) и экзистенциального (снижение с $11,6 \%$ до $9,5 \%, Z=-3,4, p<0,01)$ компонентов;

- между 7-м и 8-м классами происходят дальнейшее сокращение доли идентификации себя через различные личностные качества и рост идентификаций с малыми группами (с 5,6\% до 9,7\%, Z = 4,04, p < 0,01) и этнического (с 2,6\% до 4,2\%, Z = 3,9, p <0,01) компонентов идентичности. Также вновь наблюдается рост полоролевого компонента идентичности (с $4 \%$ до 5, $\%, Z=2,25, p<0,03$ );

- наконец, к концу подросткового возраста основные изменения приходятся на учебный (рост с 7,6\% до 8,5\%, Z = 2,84, p <0,01), семейный (рост с 12,1\% до 13,1\%, Z = 2,61, p < 0,01), деятельностный (рост с 4,6 \% до 5,4\%, $\mathrm{Z}=2,1, \mathrm{p}<0,05)$ компоненты. Доля остальных компонентов меняется незначительно.

Таким образом, можно констатировать, что изменения в структуре идентичности в ходе подросткового возраста являются противоречивыми. Наряду с тенденцией к снижению доли характеристик личности, используемых для самоописания и экзистенциального компонента идентичности, происходит рост доли самоописаний, связанных с учебной деятельностью. При этом изменения деятельностного, семейного, полоролевого, коммуникативного компонентов идентичности не являются столь же линейными. Выраженность семейной идентичности резко увеличивается к середине подросткового возраста и затем практически стабилизируется. Выраженность коммуникативной идентичности также увеличивается к середине подросткового возраста и затем остается стабильной. Полоролевой и деятельностный компоненты имеют схожую динамику: достигают локального пика в первой трети подросткового возраста и затем снижаются.

\section{Анализ динамики идентичности в юношеском возрасте}

Далее мы проанализировали динамику отдельных компонентов идентичности в юношеском возрасте в период с 2013-го по 2017-й год (соответствует курсу обучения студентов в рамках программы бакалавриата). 
Таблица 3. Аинамика отАельных Компонентов иАентичности Юношей

Table 3. Dynamics of components of identity in university students

\begin{tabular}{|c|c|c|c|c|c|c|c|c|}
\hline \multirow{2}{*}{$\begin{array}{l}\text { Компоненты } \\
\text { Components }\end{array}$} & \multicolumn{2}{|c|}{$\begin{array}{c}1 \text { курс } \\
\text { 1st grade }\end{array}$} & \multicolumn{2}{|c|}{$\begin{array}{c}2 \text { курс } \\
\text { 2nd grade }\end{array}$} & \multicolumn{2}{|c|}{$\begin{array}{c}3 \text { курс } \\
\text { 3rd grade }\end{array}$} & \multicolumn{2}{|c|}{$\begin{array}{c}4 \text { курс } \\
\text { 4th grade }\end{array}$} \\
\hline & $\begin{array}{c}4 и с- \\
10 \\
n\end{array}$ & $\%$ & $\begin{array}{c}\text { Чис- } \\
10 \\
n\end{array}$ & $\%$ & $\begin{array}{c}\text { Чис- } \\
10 \\
n\end{array}$ & $\%$ & $\begin{array}{c}4 и с- \\
10 \\
n\end{array}$ & $\%$ \\
\hline $\begin{array}{l}\text { Полоролевой } \\
\text { Gender }\end{array}$ & 214 & $4,8 \%$ & 209 & $5,1 \%$ & 229 & $5,2 \%$ & 235 & $5,3 \%$ \\
\hline $\begin{array}{l}\text { Учебно- } \\
\text { продеес- } \\
\text { сиональный } \\
\text { Educational- } \\
\text { professional }\end{array}$ & 280 & $6,3 \%$ & 301 & $7,3 \%$ & 219 & $5,0 \%$ & 312 & $7,0 \%$ \\
\hline $\begin{array}{l}\text { Семейный } \\
\text { Family }\end{array}$ & 421 & $9,5 \%$ & 464 & $11,2 \%$ & 537 & $12,3 \%$ & 567 & $12,7 \%$ \\
\hline $\begin{array}{l}\text { Этнический } \\
\text { Ethnic }\end{array}$ & 98 & $2,2 \%$ & 134 & $3,2 \%$ & 123 & $2,8 \%$ & 113 & $2,5 \%$ \\
\hline $\begin{array}{l}\text { Аичностный } \\
\text { Personal }\end{array}$ & 2127 & $49,0 \%$ & 1914 & $46,2 \%$ & 2028 & $47,4 \%$ & 2021 & $45,4 \%$ \\
\hline $\begin{array}{l}\text { Коммуни- } \\
\text { кативный } \\
\text { Communicative }\end{array}$ & 195 & $4,4 \%$ & 175 & $4,2 \%$ & 183 & $4,2 \%$ & 170 & $3,8 \%$ \\
\hline $\begin{array}{l}\text { Аеятель- } \\
\text { ностный } \\
\text { Activity }\end{array}$ & 236 & $5,3 \%$ & 187 & $4,5 \%$ & 177 & $4,1 \%$ & 173 & $3,9 \%$ \\
\hline $\begin{array}{l}\text { Перспективный } \\
\text { Prospective }\end{array}$ & 40 & $0,9 \%$ & 28 & $0,7 \%$ & 39 & $0,9 \%$ & 89 & $2,0 \%$ \\
\hline $\begin{array}{l}\text { Групповой } \\
\text { Group }\end{array}$ & 152 & $3,4 \%$ & 142 & $3,4 \%$ & 138 & $3,2 \%$ & 119 & $2,7 \%$ \\
\hline $\begin{array}{l}\text { Экзистен- } \\
\text { циальный } \\
\text { Existential }\end{array}$ & 621 & $14,0 \%$ & 593 & $14,3 \%$ & 657 & $15,0 \%$ & 649 & $14,6 \%$ \\
\hline
\end{tabular}

Прежде всего, обращает на себя внимание отсутствие серьезных изменений в структуре идентичности в целом на всем протяжении обучения в вузе. Изменения затрагивают только часть компонентов. Так, выраженность 
учебно-профессионального компонента значимо снижается к 3-му курсу (с 7,3 \% до $5 \%, Z=2,89, p<0,01$ ), однако затем резко повышается (с $5 \%$ до $7 \%, Z=2,91$, p < 0,01). Выраженность перспективного компонента идентичности также первоначально снижается, однако к окончанию вуза значимо возрастает (с 0,9\% до $2 \%, Z=3,54, p<0,01)$. При этом семейная идентичность устойчиво растет на всем протяжении студенчества (с 9,5\% до 12,7 \%, Z = 3,84, p < 0,01). Наоборот, описание себя в терминах членства в различных неформальных группах больше свойственно первокурсникам, чем выпускникам (снижение с 3,4\% до $2,7 \%, Z=2,77, \mathrm{p}<0,01)$.

В целом можно заключить, что динамика компонентов идентичности у юношей-студентов не является столь же характерной, как у подростков. На временном периоде в один год различия могут отсутствовать вовсе. Между тем, на более широких промежутках можно говорить об определенных тенденциях в идентичности. Так, семейная идентичность устойчиво растет на всем протяжении студенчества, а идентичность, связанная с неформальными группами и деятельностная идентичность, наоборот, снижаются; экзистенциальный компонент идентичности незначительно меняется как в сторону увеличения доли, так и в сторону ее снижения.

\section{Анализ динамики субъективной картины прошлого и будущего у подростков и юношей}

В ходе анализа особенностей идентичности в подростковом и юношеском возрасте мы обнаружили, что такой компонент идентичности, как «перспективная идентичность» оказывается фактически не выраженным. В связи с этим мы проанализировали содержание событий, субъективно выделяемых испытуемыми в своем прошлом, а также возможные события, которыми испытуемые наполняют свое будущее при помощи методики «Твоя линия жизни».

Во-первых, мы обнаружили преобладание в субъективной картине прошлого событий, связанных с учебной и учебно-профессиональной идентичностью, как у подростков, так и у испытуемых юношеского возраста. На этот компонент идентичности в разные периоды приходится от 34,3 \% до 42,86 \% всех событий, связанных с прошлым у испытуемых подросткового возраста, и от 27,12 \% до 35,58 \% всех событий у юношей. Столь же значимым оказывается и семейный компонент: до 23,22 \% у подростков и до 21,49\% всех событий в юношеском возрасте приходятся на данный компонент. В целом доминирующими у испытуемых являются только четыре компонента идентичности - полоролевой, учебно-профессиональный, семейный и личностный. На них приходится более 80 \% всех ответов.

Во-вторых, основная динамика субъективных представлений о своем прошлом оказывается свойственна именно испытуемым подросткового 
возраста. В период с середины подросткового возраста до его завершения у испытуемых происходит значимое снижение выраженности учебно-профессионального («пошел в школу», «перешел в другой класс» - с 42,86 \% до $34,30 \%, Z=2,04, p<0,05$ ), личностного («сломал руку», «понял, что рисование - не мое» - с 27,86 \% до 7,98\%, $Z=2,68$, p < 0,01) компонентов. Наоборот, чаще указываются события, связанные с семейным («родился брат», «развод родителей» - с 13,57 \% до 23,22 \%, Z = 2,25, p < 0,03), групповым («пошел в хоккей», «приз на танцевальном конкурсе»- с 7,01 \% до 18,60 \%, Z = 2,14, $\mathrm{p}<0,05)$ компонентами. Также отметим появление такого компонента, как экзистенциальный («переосмысление себя», «новый духовный опыт» - с 0,13\% до $3,57 \%, Z=3,14, p<0,01)$.

В то же время у испытуемых юношеского возраста содержание выделяемых в прошлом наиболее значимых событий значимо не меняется от курса к курсу. Это можно интерпретировать в смысле большей устойчивости субъективной картины прошлого по сравнению с подростками. Можно отметить лишь отсутствие упоминаний событий, относящихся к экзистенциальному компоненту, у испытуемых 3-го курса по сравнению с 1-м.

В ходе анализа событий, выделяемых в своей субъективной картине будущего испытуемыми подросткового и юношеского возраста, мы обнаружили следующее. Во-первых, было выявлено преобладание в субъективной картине будущего событий, связанных с учебной и учебно-профессиональной идентичностью как у подростков (43,3 \% всех событий), так и у испытуемых юношеского возраста (32,72 \% всех событий). Не менее значимым компонентом, чем при субъективном восприятии своего прошлого, оказывается семейныйон доминирует как у подростков (25,86 \%), так и юношей (35,21%). Из других сфер, значимых для будущего испытуемых, следует отметить личностную, групповую, а также полоролевые сферы.

Во-вторых, динамика субъективных представлений о своем будущем оказывается не выраженной ни у подростков, ни у испытуемых юношеского возраста. Исключением является только снижение выраженности полоролевого компонента («стану популярной девушкой», «заведу роман» - с 13,73\% до 5,41\%, Z = 2,28, p < 0,03) и деятельностного компонента («буду делать, что захочу, «совершу кругосветное путешествие»- с 0,36 \% до 3,76 \%, Z= 4,75, $\mathrm{p}<0,01$ ) у подростков и снижение экзистенциального компонента («пойму смысл жизни», «найду себя» - с 4,29\% до 0,50 \%, Z = 5,28, p < 0,01) у испытуемых юношеского возраста.

Таким образом, можно констатировать, что по сравнению с субъективным восприятием прошлого субъективное восприятие своего будущего оказывается у испытуемых подросткового и юношеского возраста гораздо более стабильным и неизменным. 


\section{Анализ используемых конструктов и их динамики в юношеском возрасте}

Наконец, используя теорию личностных конструктов Дж. Келли, мы провели анализ того, при помощи каких конструктов испытуемые юношеского возраста интерпретируют окружающие их социальные события, а также насколько данные конструкты являются стабильными. В целом нами были выделены два крупных типа решеток, не пересекающихся друг с другом. Первый мы определили как «индивидуально-личностный». Туда вошли испытуемые, использующие конструкты, в которых выражены признаки культуры, взаимоотношения, общения. Такие испытуемые сравнивали Других, используя какие-либо качества личности, культурные особенности и т. п.

Второй тип решеток, который можно определить как «групповой», был характерен для испытуемых, в основе системы конструктов которых преобладают признаки, близкие полоролевой, семейной, учебно-профессиональной субкультурам (родственные отношения, внешнее сходство). Они связаны с отнесением себя к определенной группе, близкой испытуемому по признаку родства, психофизиологической природы (одного с ним пола, родственники, земляки и т. п.), а также и по неформальным группам.

Данные типы решеток отчасти совпадают с теми, которые выделила Н. Л. Иванова [13]. Однако в ее случае речь шла о трех типах решеток.

На следующем этапе мы провели анализ идентификационных характеристик как в целом по испытуемым за различные периоды их обучения, так и в каждой группе. Прежде всего, мы обнаружили, что наиболее существенными темами конструктов, позволяющих дифференцировать испытуемым свое окружение, являются личностный аспект (дифференцирование окружающих по наличию либо отсутствию у них определенных качеств), коммуникативный (приятно или неприятно общение с конкретным испытуемым, является или не является он другом/подругой), полоролевой аспект (принадлежность к одному с испытуемым полу). Гораздо реже для дифференцирования испытуемых используется его принадлежность к тому или иному этносу, профессии, семье или иное основание.

Во-вторых, соотношение ведущих оснований для создания конструктов существенно не меняется у студентов от первого курса к третьему. По-прежнему на первом месте находится личностное основание, далее следуют коммуникативное и полоролевое.

Вместе с тем значение личностного основания к третьему курсу снижается (с 44,7 \% до 30,8 \%, Z = 2,11, р < 0,05). Наоборот, вырастает роль учебно-профессионального компонента (с 4,9\% до 8,4 \%, Z = 2,38, p < 0,01) и группового компонента (с 0,9\% до 2,4\%, Z = 2,85, p < 0,01) идентичности. Получается, что к третьему курсу испытуемым оказывается привычнее использовать для 
создания конструктов принадлежность к одной и той же профессии, учебной группе или неформальным объединениям, чем на первом курсе.

Таким образом, в целом у юношей наиболее популярны конструкты, в основе которых лежат гендерный аспект, личностные качества и межличностные отношения.

\section{Устойчивость компонентов идентичности в подростковом возрасте}

Если на первом этапе мы изучали доминирующие компоненты идентичности у испытуемых подросткового и юношеского возраста, то на втором этапе мы выявляли устойчивые самоописания на каждом из возрастных этапов. Для выявления устойчивых компонентов идентичности мы обратились к анализу конкретных характеристик, используемых испытуемыми подросткового возраста для самоописания, и их стабильности во времени. Для этого мы проанализировали, какая доля характеристик используется испытуемыми повторно на интервалах в один год. Фиксировались повторные указания на те или иные качества своей личности, свои действия или социальные роли, и то, как долго они использовались для самоописания.

Таблица 4. Устойчивость различных самоиАентифрикаций у поАростков

Table 4. Stability of various self-identifications in schoolchildren

\begin{tabular}{|c|c|c|c|c|c|c|c|c|}
\hline \multirow[t]{2}{*}{$\begin{array}{c}\text { Компоненты } \\
\text { Components }\end{array}$} & \multicolumn{2}{|c|}{$\begin{array}{c}\text { Межау } \\
\text { 5-м и 6-м } \\
\text { кАассом } \\
\text { Between 5th } \\
\text { form and 6th } \\
\text { form }\end{array}$} & \multicolumn{2}{|c|}{$\begin{array}{c}\text { МежАу } \\
\text { 6-м и 7-м } \\
\text { к^ассом } \\
\text { Between 6th } \\
\text { form and 7th } \\
\text { form }\end{array}$} & \multicolumn{2}{|c|}{$\begin{array}{c}\text { МежАу } \\
\text { 7-м и 8-м } \\
\text { к^ассом } \\
\text { Between 7th } \\
\text { form and 8th } \\
\text { form }\end{array}$} & \multicolumn{2}{|c|}{$\begin{array}{c}\text { МежАу } \\
\text { 8-м и 9-м } \\
\text { классом } \\
\text { Between 8th } \\
\text { form and 9th } \\
\text { form }\end{array}$} \\
\hline & $\begin{array}{c}\text { Число } \\
n\end{array}$ & $\%$ & $\begin{array}{c}\text { Число } \\
n\end{array}$ & $\%$ & $\begin{array}{c}\text { Число } \\
n\end{array}$ & $\%$ & $\begin{array}{c}\text { Число } \\
n\end{array}$ & $\%$ \\
\hline $\begin{array}{l}\text { Полоролевой } \\
\text { Gender }\end{array}$ & 30 & $6,8 \%$ & 48 & $9,4 \%$ & 32 & $10,3 \%$ & 12 & $4,9 \%$ \\
\hline $\begin{array}{l}\text { Учебный } \\
\text { Educational }\end{array}$ & 33 & $7,4 \%$ & 51 & $10,0 \%$ & 16 & $5,1 \%$ & 15 & $6,1 \%$ \\
\hline $\begin{array}{l}\text { Семейный } \\
\text { Family }\end{array}$ & 60 & $13,5 \%$ & 78 & $15,3 \%$ & 64 & $20,5 \%$ & 36 & $14,6 \%$ \\
\hline $\begin{array}{l}\text { Этнический } \\
\text { Ethnic }\end{array}$ & 3 & $0,7 \%$ & 3 & $0,6 \%$ & 0 & $0,0 \%$ & 3 & $1,2 \%$ \\
\hline $\begin{array}{l}\text { Аичностный } \\
\text { Personal }\end{array}$ & 222 & $50,0 \%$ & 198 & $38,8 \%$ & 148 & $47,4 \%$ & 114 & $46,3 \%$ \\
\hline
\end{tabular}




\begin{tabular}{|c|c|c|c|c|c|c|c|c|}
\hline \multirow[t]{2}{*}{$\begin{array}{l}\text { Компоненты } \\
\text { Components }\end{array}$} & \multicolumn{2}{|c|}{$\begin{array}{c}\text { МежАу } \\
\text { 5-м и 6-м } \\
\text { классом } \\
\text { Between 5th } \\
\text { form and 6th } \\
\text { form }\end{array}$} & \multicolumn{2}{|c|}{$\begin{array}{c}\text { МежАу } \\
\text { 6-м и 7-м } \\
\text { к^ассом } \\
\text { Between 6th } \\
\text { form and 7th } \\
\text { form }\end{array}$} & \multicolumn{2}{|c|}{$\begin{array}{c}\text { МежАу } \\
\text { 7-м и 8-м } \\
\text { классом } \\
\text { Between 7th } \\
\text { form and 8th } \\
\text { form }\end{array}$} & \multicolumn{2}{|c|}{$\begin{array}{c}\text { МежАу } \\
\text { 8-м и 9-м } \\
\text { к^ассом } \\
\text { Between 8th } \\
\text { form and 9th } \\
\text { form }\end{array}$} \\
\hline & $\begin{array}{c}\text { Число } \\
n\end{array}$ & $\%$ & $\begin{array}{c}4 и с \wedge 0 \\
n\end{array}$ & $\%$ & $\begin{array}{c}\text { Число } \\
n\end{array}$ & $\%$ & $\begin{array}{c}4 \text { исло } \\
n\end{array}$ & $\%$ \\
\hline $\begin{array}{l}\text { Коммуни- } \\
\text { кативный } \\
\text { Communi- } \\
\text { cative }\end{array}$ & 12 & $2,7 \%$ & 9 & $1,8 \%$ & 8 & $2,6 \%$ & 18 & $7,3 \%$ \\
\hline $\begin{array}{l}\text { Аеятель- } \\
\text { ностный } \\
\text { Activity }\end{array}$ & 9 & $2,0 \%$ & 12 & $2,4 \%$ & 8 & $2,6 \%$ & 15 & $6,1 \%$ \\
\hline $\begin{array}{l}\text { Перспек- } \\
\text { тивный } \\
\text { Prospective }\end{array}$ & 0 & $0,0 \%$ & 0 & $0,0 \%$ & 0 & $0,0 \%$ & 0 & $0,0 \%$ \\
\hline $\begin{array}{l}\text { Групповой } \\
\text { Group }\end{array}$ & 15 & $3,4 \%$ & 12 & $2,4 \%$ & 16 & $5,1 \%$ & 18 & $7,3 \%$ \\
\hline $\begin{array}{l}\text { Экзистен- } \\
\text { циальный } \\
\text { Existential }\end{array}$ & 60 & $13,5 \%$ & 99 & $19,4 \%$ & 20 & $6,4 \%$ & 15 & $6,1 \%$ \\
\hline
\end{tabular}

Согласно полученным данным, можно выделить следующие особенности устойчивости отдельных самоидентификаций:

- в начале подросткового возраста (5-6 класс) число испытуемых, у которых самоописания повторяются по сравнению с предыдущим периодом, достаточно небольшое - только 27 \% испытуемых используют прежние самоописания; среднее число повторов - 21,3%. При этом наиболее стабильными оказываются характеристики, относящиеся к тем или иным личностным качествам испытуемых (50\%), к представителям определенного пола (6,8\%), социального статуса («ученик»- 7,4\%), социальной роли в семье $(13,5 \%)$, а также к представителям человечества (экзистенциальные) (13,5\%);

- к середине подросткового возраста число испытуемых, у которых самоописания повторяются, возрастает до 41 \%, однако среднее число повторов уменьшается до $17 \%$. По сравнению с началом подросткового возраста более устойчивыми оказываются идентификации, относящиеся к полоролевому $(Z=-2,44, p<0,014)$, учебному $(Z=-2,01, p<0,05)$ и экзистенциальному $(Z=-2,05, p<0,05)$ аспектам; 
- ближе к концу подросткового возраста (7-8 класс) происходит резкое падение числа повторяющихся идентификаций на всей выборке подростков (с 510 до 312 повторов на всю выборку в целом). Это снижение затрагивает, прежде всего, идентификации, относящиеся к учебному процессу (снижение с $10 \%$ до 5,1 \%, Z = -3,58, p < 0,01) и экзистенциальный компонент идентичности (снижение с 19,4 \% до 6,4\%, Z =-4,11, p <0,01). Происходит рост числа повторов идентификаций, связанных с неформальными группами (с 2,4\% до 5,1%), однако в абсолютных величинах он не велик;

- наконец, к окончанию подросткового возраста (8-й и 9-й классы) можно констатировать дальнейшее снижение числа испытуемых, у которых самоописания повторяются - до $17 \%$. При этом характерно постепенное снижение процентной доли повторов, связанных с полоролевой, семейной идентичностей и экзистенциальным компонентом при одновременном росте числа повторов идентификаций, связанных с коммуникативным аспектом, деятельностью и указаниями на принадлежность к различным неформальным группам.

Таким образом, можно констатировать, что число характеристик, повторно используемых для самоописания, уменьшается от года к году на всем протяжении подросткового возраста. При этом происходит изменение долей повторно используемых самоописаний, относящихся к тому или иному аспекту идентичности. Если первоначально наибольшее число самоописаний приходится на такие компоненты, как полоролевой, учебный, семейный экзистенциальный и личностный, то затем с ними равняются такие компоненты, как коммуникативный, деятельностный, и идентификации, относящиеся к членству в неформальных группах. Наиболее повторяемыми на всем протяжении подросткового возраста оказываются такие характеристики, относящиеся к личностной идентичности, как «добрый», «умный», «красивый», «дружелюбный»; относящиеся к экзистенциальному компоненту - «человек»; относящиеся к семейному компоненту - «сын» или «дочь»; относящиеся к полоролевому компоненту - «мальчик/девочка»; относящиеся к учебной идентичности - «ученик/ученица».

При этом в ходе сопоставления изменения отдельных компонентов идентичности подростков и использования ими одних и тех же характеристик для самоописания была выделена их несовпадающая динамика. Так, при неизменной доле семейного компонента доля повторно используемых характеристик снижалась $(r=-0,67, p<0,01)$; рост доли учебного компонента не сопровождался ростом повторно используемых характеристик в середине-конце подросткового возраста ( $r=-0,72, p<0,05)$; при относительной устойчивости личностного компонента в целом число повторно используемых характеристик к концу подросткового возраста также снижалось $(r=-0,36, p<0,01)$. 
Таким образом, можно заключить следующее. Чем большую долю занимает тот или иной компонент идентичности, тем более дифференцированным он оказывается, и тем менее склонен испытуемый к повторному использованию самоидентификаций. Если рассматривать число упоминаний как показатель значимости для испытуемых того или иного компонента идентичности, то получается следующее: повторное использование одних и тех же самоописаний спустя год свидетельствует скорее о том, что данная идентификация не развивается, чем о том, что она является принципиально важной для испытуемого.

Вместе с тем даже и при расширении репертуара используемых самоидентификаций меняются далеко не все. Часть из них стабильно встречается в ответах испытуемых на протяжении всего подросткового возраста. Поэтому мы проанализировали характеристики использованных повторно испытуемыми два и более раз (т. е. стабильно встречавшихся в ответах на протяжении трех лет и больше), а затем сопоставили их с тем, какое количество повторов в среднем допускали испытуемые в каждом из компонентов идентичности.

Согласно полученным данным, устойчивым у подростков оказывался только личностный компонент идентичности. Хотя в среднем доля повторно использованных характеристик составляла для этого компонента 45,6 \%, доля характеристик, использованных дважды и чаще, была равна 59,1 \% ( $\varphi=2,91$, $\mathrm{p}<0,01)$. Наоборот, доля дважды и чаще используемых самокатегоризаций, относимых к семейному и групповому компонентам идентичности, оказалась меньше, чем доля повторов на меньшем промежутке времени у них же $(\varphi=2,92$, $\varphi=1,7$ соответственно, $p<0,01)$. Это можно интерпретировать в том смысле, что в ходе развития идентичности содержание данных компонентов существенно изменилось, и большинство характеристик перестали использоваться повторно.

Таким образом, можно сделать вывод, что наиболее устойчивые идентификации на всем протяжении подросткового возраста относятся к личностному компоненту идентичности. Хотя к концу подросткового возраста увеличивается разнообразие самоидентификаций, относимых к данному компоненту, тем не менее, доля характеристик, используемая два раза и чаще, выше именно в личностной идентичности.

\section{Устойчивость компонентов идентичности в юношеском возрасте}

На данном этапе для выявления устойчивых компонентов идентичности мы обратились к анализу конкретных характеристик, используемых испытуемыми в юношеском возрасте для самоописания, и их стабильности во времени. Результаты представлены по конкретным компонентам идентичности в таблице 5 . 
Таблица 5. Устойчивость различных самоилентифрикаций в юношеском возрасте

Table 5. Stability of various self-identifications in university students

\begin{tabular}{|c|c|c|c|c|c|c|}
\hline \multirow[t]{2}{*}{$\begin{array}{l}\text { Компоненты } \\
\text { Components }\end{array}$} & \multicolumn{2}{|c|}{$\begin{array}{l}\text { Межау 1-м } \\
\text { и 2-м курсом } \\
\text { Between 1st } \\
\text { grade and 2nd } \\
\text { grade }\end{array}$} & \multicolumn{2}{|c|}{$\begin{array}{c}\text { Межау 2-м } \\
\text { и 3-м курсом } \\
\text { Between 2nd } \\
\text { grade and 3rd } \\
\text { grade }\end{array}$} & \multicolumn{2}{|c|}{$\begin{array}{c}\text { Межау 3-м } \\
\text { и 4-м курсом } \\
\text { Between 3rd } \\
\text { grade and 4th } \\
\text { grade }\end{array}$} \\
\hline & $\begin{array}{c}\text { Число } \\
n\end{array}$ & $\%$ & $\begin{array}{c}\text { Число } \\
n\end{array}$ & $\%$ & $\begin{array}{c}\text { Число } \\
n\end{array}$ & $\%$ \\
\hline $\begin{array}{l}\text { Полоролевой } \\
\text { Gender }\end{array}$ & 130 & $11,6 \%$ & 138 & $12,3 \%$ & 130 & $11,6 \%$ \\
\hline $\begin{array}{l}\text { Учебно-профрес- } \\
\text { сиональный } \\
\text { Educational- } \\
\text { professional }\end{array}$ & 145 & $12,9 \%$ & 160 & $14,3 \%$ & 66 & $5,9 \%$ \\
\hline $\begin{array}{l}\text { Семейный } \\
\text { Family }\end{array}$ & 190 & $16,9 \%$ & 195 & $17,4 \%$ & 124 & $11,1 \%$ \\
\hline $\begin{array}{l}\text { Этнический } \\
\text { Ethnic }\end{array}$ & 25 & $2,2 \%$ & 29 & $2,6 \%$ & 24 & $2,1 \%$ \\
\hline $\begin{array}{l}\text { Аичностный } \\
\text { Personal }\end{array}$ & 280 & $25,0 \%$ & 295 & $26,3 \%$ & 315 & $28,1 \%$ \\
\hline $\begin{array}{l}\text { Коммуникативный } \\
\text { Communicative }\end{array}$ & 40 & $3,6 \%$ & 38 & $3,4 \%$ & 30 & $2,7 \%$ \\
\hline $\begin{array}{l}\text { Аеятельностный } \\
\text { Activity }\end{array}$ & 88 & $7,9 \%$ & 90 & $8,0 \%$ & 40 & $3,6 \%$ \\
\hline $\begin{array}{l}\text { Перспективный } \\
\text { Prospective }\end{array}$ & 5 & $0,4 \%$ & 7 & $0,6 \%$ & 20 & $1,8 \%$ \\
\hline $\begin{array}{l}\text { Групповой } \\
\text { Group }\end{array}$ & 58 & $5,2 \%$ & 52 & $4,6 \%$ & 54 & $4,8 \%$ \\
\hline $\begin{array}{l}\text { Экзистенциальный } \\
\text { Existential }\end{array}$ & 160 & $14,3 \%$ & 148 & $13,2 \%$ & 155 & $13,8 \%$ \\
\hline
\end{tabular}




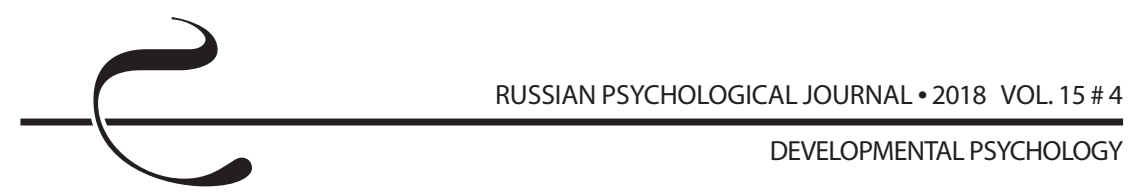

Во-первых, обращает на себя внимание структура повторно используемых характеристик. Так, только четверть из них приходится на личностный компонент идентичности (от 25 \% до 28,1 \%). В основном повторно используются характеристики, относящиеся к семейному (от 11,1 \% до 17,4 \%), учебно-профессиональному (от 5,9 \% до 14,3 \%), экзистенциальному (от 13,2 \% до 14,3\%), полоролевому (от 11,6 \% до 12,3\%) компонентам.

Во-вторых, следует отметить резкое снижение числа повторно используемых характеристик в различные периоды обучения. Так, между 3-м и 4-м курсом происходит резкое снижение повторно используемых характеристик, относящихся к учебно-профессиональному (снижение с 14,3\% до 5,9\%, $Z=5,66, p<0,01$ ), семейному (снижение с $17,4 \%$ до $11,1 \%, Z=4,58, p<0,01$ ) деятельностному (снижение с $8 \%$ до $3,6 \%, Z=4,19, p<0,01$ ) компонентам.

Как и в случае с подростками, мы отметили несовпадающую динамику выраженности компонентов и числа повторно используемых характеристик: по семейной идентичности в целом и повторно используемым характеристикам ( $r=-0,44, p<0,01)$, по учебному компоненту в целом и повторно используемым характеристикам в конце периода студенчества $(r=-0,48, p<0,05)$, по деятельностному компоненту в целом и повторно используемым характеристикам к концу студенчества $(r=-0,36, p<0,05)$. Получается, что у юношей к концу обучения в вузе рост выраженности отдельных компонентов идентичности оказывается связан с большей дифференциацией используемых характеристик; испытуемые реже используют отдельные самоидентификации повторно. Вместе с тем, как и в случае с подростками, даже и при расширении репертуара используемых самоидентификаций последние меняются далеко не все. Часть из них стабильно встречается в ответах испытуемых на протяжении всего юношеского возраста. Поэтому далее мы проанализировали характеристики, использованные повторно испытуемыми два раза и чаще (т. е. стабильно встречавшиеся в ответах на протяжении трех лет и больше).

Согласно полученным данным, устойчивым у испытуемых юношеского возраста оказывался только перспективный компонент идентичности. Хотя в среднем доля повторно использованных характеристик составляла для этого компонента 0,9\%, доля характеристик, использованных дважды и чаще, была равна $3,2 \%(\varphi=2,93, \mathrm{p}<0,01)$. При этом интересен состав характеристик. В абсолютном большинстве случаев это были указания на будущие семейные («будущая жена», «будущая мама» и т. п.) и профессиональные («будущий “представитель профессии"») роли. Заметим, что никаких различий в средней частоте использования различных характеристик и в частоте их использования дважды и чаще ни в семейном, ни в учебно-профессиональном компонентах мы не обнаружили. Это можно интерпретировать в том смысле, что в ходе развития идентичности содержание данных компонентов 
существенно изменилось, и большинство характеристик перестали использоваться повторно.

\section{Анализ устойчивости субъективной картины прошлого и будущего у подростков и юношей}

В этой связи рассмотрим, какую долю составляют повторно указываемые события при репрезентации своего прошлого и будущего испытуемыми подросткового и юношеского возраста.

Анализ повторно указываемых событий при репрезентации своего прошлого испытуемыми подросткового и юношеского возраста показал, что наибольшая доля из них приходится на учебно-профессиональный $(42,17 \%)$ и семейный $(41,1 \%)$ компоненты. В совокупности на них приходится более 80 \% всех повторно используемых характеристик испытуемыми подросткового возраста и более 75 \% - испытуемыми юношеского возраста (39,15 \% и 37,4\% соответственно). При том, что личностный компонент идентичности оказывался достаточно выражен как у подростков, так и у испытуемых юношеского возраста, на него приходится только 3,19\% и 7,1 \% всех повторов соответственно.

Анализ повторно указываемых событий при репрезентации своего будущего подростками и юношами оказался аналогичен распределению соответствующих компонентов в ответах испытуемых в целом. Как мы указали выше, репрезентация будущего как подростками, так и испытуемыми юношеского возраста оказывается практически неизменной. Ее основу составляют планы испытуемых закончить учебное заведение (школу и вуз соответственно), продолжить учебу или начать трудовую деятельность, в перспективе жениться / выйти замуж и завести детей.

Таким образом, можно сделать следующие выводы:

- во-первых, субъективная картина прошлого в подростковом возрасте оказывается гораздо более изменчивой, чем в юношеском. Хотя и в том и в другом случае основными компонентами данной картины являются события недавнего прошлого (связанные, прежде всего, с учебно-профессиональными, семейными аспектами или с принадлежностью к различным малым группам), однако в подростковом возрасте их субъективная значимость оказывается более лабильной, чем в юношеском;

- во-вторых, субъективная картина будущего в подростковом, так и в юношеском возрасте оказывается более устойчивой во времени. Во многом это связано с тем, что ее основу составляют общие для подростков и юношей предполагаемые в будущем события (начало семейной жизни, начало трудовой деятельности);

- в-третьих, устойчивую основу как репрезентации своего прошлого, так и своего будущего, составляют события, относящиеся к учебной 
и семейной сферам. Как у подростков, так и у школьников их доля оказывается максимальной (до 80 \%) среди повторно указываемых событий, как прошлого, так и предполагаемого будущего.

\section{Анализ устойчивости используемых конструктов у юношей}

Анализируя понятия, повторно используемые для построения конструктов испытуемыми юношеского возраста, отметим следующие особенности. Во-первых, наибольшее число повторов (34 \% от общего их числа) пришлось на личностные характеристики. При этом в основу конструктов брались наиболее общие понятия - «приятный/неприятный», «хороший/плохой» человек. Во-вторых, до 22 \% и до 23 \% всех повторов пришлись на характеристики, связанные с семьей и с приятельскими отношениями, главные из которых - «родной/неродной» человек либо «друг (приятель) / незнакомый человек (не друг)». Наконец, до 17 \% всех повторов пришлись на компоненты, связанные с учебой либо профессией («вместе учимся / не учимся», «коллега / посторонний человек», «одной со мной специальности / учится на другой»).

Таким образом, хотя юноши, в основном, используют конструкты, связанные с гендерной принадлежностью, качествами личности и межличностными связями, однако наибольшей устойчивостью во времени обладают конструкты, связанные с наиболее общими качествами личности («приятный/ неприятный», «хороший/плохой» человек), связанные с семьей и с приятельскими отношениями («родной/неродной», «друг (приятель) / незнакомый человек (не друг)») и с учебой либо профессией («вместе учимся / не учимся», «коллега / посторонний человек», «одной со мной специальности / учится на другой»).

\section{Обсуждение результатов}

В целом, с точки зрения доминирования тех или иных компонентов в подростковом и юношеском возрасте, следует отметить ведущее место личностной идентичности; среди компонентов социальной идентичности -учебно-профессионального, семейного, полоролевого, группового (у подростков). При некоторых различиях в динамике данные компоненты оказывались достаточно выраженными вне зависимости от возраста. Эти выводы согласуются с ранее полученными результатами $[14,15,16]$ на более коротких возрастных периодах.

Полученные нами результаты согласуются и с выводами других исследователей. А. В. Микляева и П. В. Румянцева отмечали, что в подростковом и в более зрелом возрасте испытуемые прежде всего идентифицируют себя с ролью «ученика» (студента), а также с гендерными и возрастными ролями [17]. По Г. Б. Мазиловой, на долю профессиональной, ролевой позиции 
приходилось 13,9\%, восприятия себя членом семьи - 8,2 \%, рефлексивной самоидентичности - от $17 \%$ до $29,9 \%$ [8].

Выявленная нами динамика идентичности в ряде аспектов соответствует и данным зарубежной психологии. По данным ряда авторов (например, H. Bosma [18]), E. Crocetti et al., учебная идентичность является ключевым аспектом самоопределения и основой будущего планирования своей жизни у подростков и юношей [7].

Сложнее обстоит дело с другими компонентами. В исследованиях Z. Abdukeram et al. [19], Ch. Tanti et al. [20] фиксируется рост межличностного компонента идентичности (relational) в подростковом возрасте. Согласно данным E. Crocetti, у этого компонента идентичности весьма сложная структура, отличающаяся от возраста к возрасту [7]. Так, по мнению C. Sherif \& M. Sherif [21], I. De Goede et al. [22], M. Helsen et al. [23], в подростковом возрасте его основу составляют отношения с лучшими друзьями. В то же время, при переходе к ранней взрослости характерно доминирование либо идентификация со своей ролью романтического партнера [24], либо семейного компонента идентичности. Мы не зафиксировали доминирования коммуникативного компонента идентичности в подростковом возрасте (именно туда мы относили самоописания, связанные с приятельскими отношениями). Однако такой выделенный нами компонент идентичности, как интегральная идентичность с неформальными группами, может совпадать с указанным межличностным (relational) компонентом, о котором писали Z. Abdukeram, Ch. Tanti. Данное предположение мы высказывали в нашем предыдущем исследовании [16].

Говоря об устойчивости отдельных компонентов идентичности, отметим следующее. В отечественной психологии достаточно мало работ, с которыми мы можем соотнести полученные нами результаты. В исследовании Н. В. Писаренко сопоставляются наиболее характерные для юношей и девушек роли, однако не приводятся конкретные самоидентификации [25]. В работе В. Л. Ситникова представлен подробный обзор характеристик, которые используют для самоописания школьники различного возраста. Согласно полученным им данным, для старшеклассников наиболее востребованными являются характеристики «добрый» $(57 \%$ - $59 \%$ для девушек и юношей), «умный» (41 \% - 58 \% для девушек и юношей). Гораздо реже встречаются характеристики, относящиеся к семейному («сын/дочь» - $7 \%$ - 12\%), полоролевому («юноша/девушка» - 12 \% у девушек), экзистенциальному («человек» - 7 \% у юношей) [26]. И хотя В. Л. Ситников использует свой авторский способ обработки методики «Двадцать утверждений» (что не позволяет распределить характеристики по выделяемым нами компонентам), в целом выявленные им наиболее популярные самоидентификации согласуются с полученными нами данными. 


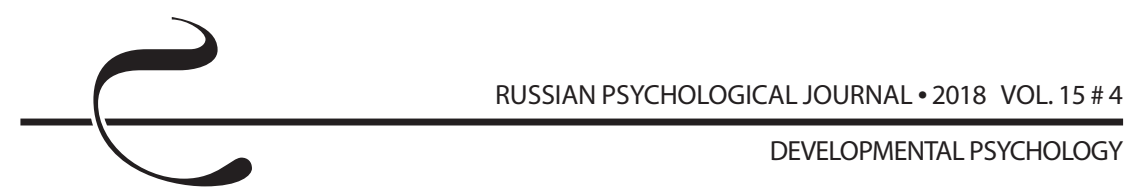

При этом В. Л. Ситников не изучал динамику самоописаний испытуемых, отмечая, в частности, что в различные возрастные периоды смысл, вкладываемый в ту или иную характеристику самим испытуемым (например, в понятие «умный»), может меняться [26]. Вместо этого он предлагал сравнивать, насколько совпадают самоописание испытуемого и описание его же со стороны (обычно родителя или учителя), фиксируя количество совпадений.

Мы не нашли зарубежных работ, описывающих составляющие «ядра» идентичности в виде стабильности отдельных самокатегоризаций в целом, хотя в ряде работ (например, D. Addis \& L. Tippett [27], D. J. Feenstra et al. [28]) отмечается их важность. Тем не менее, в отдельных работах рассматриваются закономерности стабильности или изменчивости отдельных компонентов идентичности. Так, D. Hughes, N. Way \& D. Rivas-Drake описывали стабильность этнической идентичности подростков, принадлежащих к разным культурам [29]. Y. Ferguson, K. Ferguson \& G. Ferguson на примере замбийских подростков показали, как этническая идентичность замбийских подростков может быть подвергнута дистанционной аккультурации и при каких условиях она остается стабильной [30]. В работе R. Savin-Williams, K. Joyner \& G. Rieger рассматривалась стабильность сексуальной идентичности (дословно - sexual orientation identity) у подростков [31]. Однако в данных исследованиях авторы не заостряли внимание на устойчивости конкретных самоописаний.

\section{Заключение}

Полученные данные и их анализ позволяют заключить следующее:

- изменения в структуре идентичности в ходе подросткового возраста являются противоречивыми. Наряду с тенденцией к снижению доли характеристик личности, используемых для самоописания и экзистенциального компонента идентичности, происходит рост доли самоописаний, связанных с учебной деятельностью. При этом изменения деятельностного, семейного, полоролевого, коммуникативного компонентов идентичности не являются линейными;

- динамика компонентов идентичности у юношей-студентов менее выражена, чем у подростков. Семейная идентичность устойчиво растет на всем протяжении студенчества; описание себя в терминах членства в различных неформальных группах, как и деятельностная идентичность, имеет тенденцию к снижению;

- при репрезентации своего прошлого и будущего доминирующими у испытуемых как подросткового, так и юношеского возраста являются только четыре компонента идентичности - полоролевой, учебно-профессиональный, семейный и личностный. При этом основная динамика субъективных представлений о своем прошлом оказывается свойственна именно 
испытуемым подросткового возраста; у испытуемых юношеского возраста она более стабильна;

- испытуемые юношеского возраста используют конструкты, основанные на полоролевой принадлежности, определенных личностных качествах, степени близости к ним людей;

- в подростковом возрасте, чем большую долю занимает тот или иной компонент идентичности, тем более дифференцированным он оказывается, и тем менее склонен испытуемый к повторному использованию самоидентификаций;

- наиболее устойчивые идентификации в подростковом возрасте относятся к личностному компоненту идентичности, а в юношеском - к социальному;

- основными компонентами субъективной картины прошлого и будущего в подростковом и юношеском возрасте являются события, связанные прежде всего с учебно-профессиональными, семейными аспектами или с принадлежностью к различным малым группам;

- у испытуемых юношеского возраста наибольшей устойчивостью во времени обладают конструкты, связанные с наиболее общими качествами личности, с семьей, приятельскими отношениями, и с учебой либо профессией.

\section{Литература}

1. Белинская Е. П. Изменчивость Я: кризис идентичности или кризис знания о ней? // Психологические исследования. 2015. T. 8, № 40. С. 12. URL: http://psystudy.ru (дата обращения: 01.03.2018).

2. Breakwell G. M. Resisting representations and identity processes // Papers on Social Representations. 2010. Vol. 19. P. 6.1-6.11.

3. Markus H., Nurius P. Possible Selves // American Psychologist. 1986. Vol. 41, № 9. P. 954-969.

4. Иванова Н. Л. Психологическая структура социальной идентичности: дисс. ... д. психол. н. Ярославль, 2003. 408 с.

5. Klimstra T. A., Hale III W. W., Raaijmakers Q. A. W., Branje S. J. T., Meeus W. H. J. Identity Formation in Adolescence: Change or Stability? // Journal of Youth and Adolescence. 2010. Vol. 39, Issue 2. P. 150-162. DOI: 10.1007/s10964009-9401-4

6. Meeus W., van de Schoot R., Keijsers L., Schwartz S. J., Branje S. On the progression and stability of adolescent identity formation: A five-wave longitudinal study in early-to-middle and middle-to-late adolescence // Child Development. 2010. Vol. 81, Issue 5. P. 1565-1581.

7. Crocetti E., Fermani A., Pojaghi B., Meeus W. Identity Formation in Adolescents from Italian, Mixed, and Migrant Families // Child \& Youth Care Forum. 2011. Vol. 40, Issue 1. P. 7-23. DOI: $10.1007 /$ s10566-010-9112-8 
8. Мазилова Г. Б. Динамика социальной идентичности личности в современном обществе: дисс. ... канд. психол. н. Ярославль, 2006. 203 с.

9. Румянцева Т. В. Трансформация идентичности студентов медицинского вуза в меняющихся социальных условиях: дисс. ... канд. психол. н. Ярославль, 2005. 219 с.

10. Kuhn M. H., McPartland T. S. The Empirical Investigation of Self-attitude // American Sociological Review. 1954. Vol. 19, № 1.P. 68-76. DOI: $10.2307 / 2088175$

11. Лидерс А. Г. Психологическое обследование семьи: учеб. пособие-практикум для студ. фак. психологии высш. учеб. заведений. 2-е изд. М.: Академия, 2007. 432 с.

12. Kelly G. A. The Psychology of Personal Constructs. London: Routledge, 1991. $447 \mathrm{p}$.

13. Иванова Н. Л. Проблема психологического анализа социальной идентичности // Психология. Журнал Высшей школы экономики. 2006. Т. 3, № 4. С. 14-38.

14. Кузьмин М. Ю. Сравнение идентичности младших школьников, подростков и лиц юношеского возраста // Сибирский психологический журнал. 2015. № 58. С. 61-75. DOI: 10.17223/17267080/58/4

15. Кузьмин М. Ю. Особенности динамики идентичности младших школьников, подростков и лиц юношеского возраста // Сибирский психологический журнал. 2016. № 62. C. 54-66. DOI: 10.17223/17267080/62/5

16. Кузьмин М. Ю. Сравнение идентичности и ее динамики у младших школьников, подростков и лиц юношеского возраста // Российский психологический журнал. 2017. T. 14, № 2. C. 67-89. DOI: 10.21702/rpj.2017.2.4

17. Микляева А. В., Румянцева П. В. Социальная идентичность личности: содержание, структура, механизмы формирования: монография. СПб.: Изд-во РГПУ им. А. И. Герцена, 2008. 118 с.

18. Bosma H.A. Identity development in adolescence: Coping with commitments // Unpublished doctoral dissertation. Groningen, the Netherlands: State University, 1985.30 p. URL: https://www.researchgate.net/publication/312210619 Chapter based on 'Identity development in adolescence coping with commitments' thesis 1985 (Accessed 23 November 2018).

19. Abdukeram Z., Mamat M., Lou W., Wu Y. Influence of Culture on Tripartite SelfConcept Development in Adolescence: A Comparison between Han and Uyghur Cultures // Psychological Reports. 2015. Vol. 116, Issue 1. P. 292-310. DOI: 10.2466/17.07.PR0.116k12w8

20. Tanti Ch., Stukas A. A., Halloran M. J., Foddy M. Tripartite Self-concept Change: Shifts in the Individual, Relational, and Collective Self in Adolescence // Self and Identity. 2008. Vol. 7, Issue 4. P. 360-379. DOI: $\underline{10.1080 / 15298860701665081}$ 
21. Sherif M., Sherif C. W. Reference Groups: Exploration Into Conformity and Deviation of Adolescents. New York: Harper and Row, 1964. 370 p.

22. De Goede I. H. A., Branje S. J. T., Meeus W. H. J. Developmental changes and gender differences in adolescents' perceptions of friendships // Journal of Adolescence. 2009. Vol. 32, Issue 5. P. 1105-1123. DOI: 10.1016/j.adolescence.2009.03.002

23. Helsen M., Vollebergh W., Meeus W. Social Support from Parents and Friends and Emotional Problems in Adolescence // Journal of Youth and Adolescence. 2000. Vol. 29, Issue 3. P. 319-335. DOI: $10.1023 / \mathrm{A}: 1005147708827$

24. Stephanou G. Romantic Relationships in Emerging Adulthood: PerceptionPartner Ideal Discrepancies, Attributions, and Expectations // Scientific Research. 2012. Vol. 3, № 2. P. 150-160. DOI: 10.4236/psych.2012.32023

25. Писаренко Н. В. Феноменологический анализ опыта самоидентификации студентов в социально-психологическом «Имидж-тренинге» // Сибирский психологический журнал. 2002. № 16-17. С. 23-27.

26. Ситников В. Л. Образ ребенка в сознании детей и взрослых: монография. СПб.: Химиздат, 2001. 288 с.

27. Addis D. R., Tippett L. Memory of myself: Autobiographical memory and identity in Alzheimer's disease // Memory. 2004. Vol. 12, Issue 1. P. 56-74. DOI: $10.1080 / 09658210244000423$

28. Feenstra D. J., Hutsebaut J., Verheul R., van Limbeek J. Identity: Empirical Contribution: Changes in the Identity Integration of Adolescents in Treatment for Personality Disorders // Journal of Personality Disorders. 2014. Vol. 28, Issue 1, Special Issue: A Developmental Psychopathology Perspective on Personality Disorder. P. 101-112. DOI: 10.1521/pedi.2014.28.1.101

29. Hughes D., Way N., Rivas-Drake D. Stability and Change in Private and Public Ethnic Regard Among African American, Puerto Rican, Dominican, and Chinese American Early Adolescents // Journal of Research on Adolescence. 2011. Vol. 21, Issue 4. P. 861-870. DOI: 10.1111/j.1532-7795.2011.00744.x

30. Ferguson Y. L., Ferguson K. T., Ferguson G. M. I am AmeriBritSouthAfricanZambian: Multidimensional remote acculturation and well-being among urban Zambian adolescents // International Journal of Psychology. 2017. Vol. 52, Issue 1. P. 67-76. DOI: 10.1002/ijop.12191

31. Savin-Williams R. C., Joyner K., Rieger G. Prevalence and Stability of Self-Reported Sexual Orientation Identity During Young Adulthood // Archives of Sexual Behavior. 2012. Vol. 41, Issue 1. P. 103-110. DOI: 10.1007/s10508-012-9913-y

\section{References}

1. Belinskaya E. P. The variability of the self: an identity crisis or a crisis of knowledge about it? Psychological Studies, 2015, V. 8, no. 40, p. 12 (in Russian). Available at: http://psystudy.ru (Accessed 01 March 2018). 
2. Breakwell G. M. Resisting representations and identity processes. Papers on Social Representations, 2010, V. 19, pp. 6.1-6.11.

3. Markus H., Nurius P. Possible Selves. American Psychologist, 1986, V. 41, no. 9, pp. 954-969.

4. Ivanova N. L. Psikhologicheskaya struktura sotsial'noi identichnosti [Psychological structure of social identity]. Diss. Dr. Sci. (Psych.). Yaroslavl, 2003. $408 \mathrm{p}$.

5. Klimstra T. A., Hale III W. W., Raaijmakers Q. A. W., Branje S. J. T., Meeus W. H. J. Identity formation in adolescence: Change or stability? Journal of Youth and Adolescence, 2010, V. 39, Issue 2, pp. 150-162. DOI: 10.1007/s10964009-9401-4

6. Meeus W., van de Schoot R., Keijsers L., Schwartz S. J., Branje S. On the progression and stability of adolescent identity formation: A five-wave longitudinal study in early-to-middle and middle-to-late adolescence. Child Development, 2010, V. 81, Issue 5, pp. 1565-1581.

7. Crocetti E., Fermani A., Pojaghi B., Meeus W. Identity formation in adolescents from Italian, mixed, and migrant families. Child \& Youth Care Forum, 2011, V. 40, Issue 1, pp. 7-23. DOI: 10.1007/s10566-010-9112-8

8. Mazilova G. B. Dinamika sotsial'noi identichnosti lichnosti v sovremennom obshchestve [Dynamics of social identity in modern society]. Diss. Cand. Sci. (Psych.). Yaroslavl, 2006. 203 p.

9. Rumyantseva T. V. Transformatsiya identichnosti studentov meditsinskogo vuza v menyayushchikhsya sotsial'nykh usloviyakh [Transformation of identity of medical university students in changing social conditions]. Diss. Cand. Sci. (Psych.). Yaroslavl, 2005. 219 p.

10. Kuhn M. H., McPartland T. S. The empirical investigation of self-attitude. American Sociological Review, 1954, V. 19, no. 1, pp. 68-76. DOI: $10.2307 / 2088175$

11. Liders A. G. Psikhologicheskoe obsledovanie sem'i [Psychological examination of the family]. Moscow, Akademiya Publ., 2007. 432 p.

12. Kelly G. A. The psychology of personal constructs. London, Routledge, 1991. $447 \mathrm{p}$.

13. Ivanova N. L. Psychological analysis of social identity. Psikhologiya. Zhurnal Vysshei shkoly ekonomiki - Psychology. Journal of the Higher School of Economics, 2006, V. 3, no. 4, pp. 14-38 (in Russian).

14. Kuzmin M. Y. Comparing identities of university students and primary and secondary schoolchildren. Sibirskiy psikhologicheskiy zhurnal-Siberian Journal of Psychology, 2015, no. 58, pp. 61-75 (in Russian). DOI: $10.17223 / 17267080 / 58 / 4$

15. Kuzmin M. Y. Dynamics of identities of primary and secondary schoolchildren and university students. Sibirskiy psikhologicheskiy zhurnal - Si- 
berian Journal of Psychology, 2016, no. 62, pp. 54-66 (in Russian). DOI: $10.17223 / 17267080 / 62 / 5$

16. Kuzmin M. Y. Comparison of identity and its dynamics in primary and secondary schoolchildren and university students. Rossiiskii psikhologicheskii zhurnal - Russian Psychological Journal, 2017, V. 14, no. 2, pp. 67-89 (in Russian). DOI: 10.21702/rpj.2017.2.4

17. Miklyaeva A. V., Rumyantseva P. V. Sotsial'naya identichnost' lichnosti: soderzhanie, struktura, mekhanizmy formirovaniya [The individual's social identity: The content, structure, and formation mechanisms]. St. Petersburg, Herzen State Pedagogical University of Russia Publ., 2008. 118 p.

18. Bosma H. A. Identity development in adolescence: Coping with commitments. Unpublished doctoral dissertation. Groningen, the Netherlands: State University, 1985. 30 p. URL: https://www.researchgate.net/publication/312210619 Chapter based on 'Identity development in adolescence coping with commitments' thesis 1985 (Accessed 23 November 2018).

19. Abdukeram Z., Mamat M., Lou W., Wu Y. Influence of culture on tripartite self-concept development in adolescence: A comparison between Han and Uyghur cultures. Psychological Reports, 2015, V. 116, Issue 1, pp. 292-310. DOI: 10.2466/17.07.PR0.116k12w8

20. Tanti Ch., Stukas A. A., Halloran M. J., Foddy M. Tripartite self-concept change: Shifts in the individual, relational, and collective self in adolescence. Self and Identity, 2008, V. 7, Issue 4, pp. 360-379. DOI: 10.1080/15298860701665081

21. Sherif M., Sherif C.W. Reference groups: Exploration into conformity and deviation of adolescents. New York, Harper and Row, 1964. 370 p.

22. De Goede I.H. A., Branje S. J.T., MeeusW.H. J. Developmental changes and gender differences in adolescents' perceptions of friendships. Journal of Adolescence, 2009, V. 32, Issue 5, pp. 1105-1123. DOI: 10.1016/j.adolescence.2009.03.002

23. Helsen M., Vollebergh W., Meeus W. Social support from parents and friends and emotional problems in adolescence. Journal of Youth and Adolescence, 2000, V. 29, Issue 3, pp. 319-335. DOI: 10.1023/A:1005147708827

24. Stephanou G. Romantic relationships in emerging adulthood: Perceptionpartner ideal discrepancies, attributions, and expectations. Scientific Research, 2012, V. 3, no. 2, pp. 150-160. DOI: $10.4236 /$ psych. 2012.32023

25. Pisarenko N. V. Phenomenological analysis of the experience of the student's self-identification in the social-psychological "image-training". Sibirskii psikhologicheskii zhurnal - Siberian Journal of Psychology, 2002, no. 16-17, pp. 23-27 (in Russian).

26. Sitnikov V. L. Obraz rebenka v soznanii detei i vzroslykh [The image of the child in the minds of children and adults]. St. Petersburg, Khimizdat Publ., 2001. $288 \mathrm{p}$. 
27. Addis D. R., Tippett L. Memory of myself: Autobiographical memory and identity in Alzheimer's disease. Memory, 2004, V. 12, Issue 1, pp. 56-74. DOI: 10.1080/09658210244000423

28. Feenstra D. J., Hutsebaut J., Verheul R., van Limbeek J. Identity: Empirical contribution: Changes in the identity integration of adolescents in treatment for personality disorders. Journal of Personality Disorders, 2014, V. 28 , Issue 1, Special Issue: A Developmental Psychopathology Perspective on Personality Disorder, pp. 101-112. DOI: 10.1521/pedi.2014.28.1.101

29. Hughes D., Way N., Rivas-Drake D. Stability and change in private and public ethnic regard among African American, Puerto Rican, Dominican, and Chinese American early adolescents. Journal of Research on Adolescence, 2011, V. 21, Issue 4, pp. 861-870. DOI: 10.1111/j.1532-7795.2011.00744.x

30. Ferguson Y. L., Ferguson K. T., Ferguson G. M. I am AmeriBritSouthAfricanZambian: Multidimensional remote acculturation and well-being among urban Zambian adolescents. International Journal of Psychology, 2017, V. 52, Issue 1, pp. 67-76. DOI: 10.1002/ijop.12191

31. Savin-Williams R. C., Joyner K., Rieger G. Prevalence and stability of selfreported sexual orientation identity during young adulthood. Archives of Sexual Behavior, 2012, V. 41, Issue 1, pp. 103-110. DOI: 10.1007/s10508012-9913-y 